\section{ВЫБОР СПЕКТРАЛЬНОГО}

\section{ДИАПАЗОНА ДЛЯ СИСТЕМ ДОСМОТРА В ТЕРАГЕРЦЕВОМ}

\section{ДИАПАЗОНЕ}

\author{
В. В. Стариев, В. К. Попов, В.И. Войтов, \\ АО «ОКБ АСТРОН", \\ www.astrohn.ru, www.astrohn.com, \\ Льткарино, Моск.обл., Россия
}

\begin{abstract}
Разработан комплекс обнаружения запрещенных веществ при их скрытом проносе в элементах одежды. Комплекс работает в видимом, ИКи ТГц-диапазонах. Проведены спектральные исследования коэффициентов пропускания ТГцизлучения образцами упаковочных материалов и тканей: хлопчатобумажная, джинсовая, шерстяная ткани, свиная кожа, полиэтилен (толщиной около 0,2 мм), бумага (толщиной около 0,2 мм). Определена область частот, в которой все образцы упаковочных материалов и тканей одежды наиболее прозрачны.
\end{abstract}

Статья поступила в редакцию 07.05.2019 Статья принята к публикации 28.05.2019

\section{И} звестен ряд публикаций по результатам измерений спектральных коэффициентов пропускания терагерцевого (ТГц) излучения тканями и упаковочными веществами [1-3]. Однако данные, полученные в разных лабораториях, отличаются друг от друга, поэтому встала задача их экспериментальной проверки. Специ алисты АО “ОКБ "Астрон" проводили такие испытания на этапе разработки комплекса обнаружения запрещенных веществ при их скрытом проносе в элементах одежды. Комплекс предназначен для работы в видимом, ИК- и ТГц-диапазонах. Эти результаты были представлены в обзоре развития систем ТГц-детектирования [1]. Настоящая статья посвящена вопросу выбора спектрального диапа зона, оптимального для работы ТГц-изображающей системы.

K моменту начала исследований однозначный вид спектрального коэффициента пропускания ТГц-излучения атмосферой был не известен. Поэтому с целью выбора оптимального для построения ТГц-изображающей системы окна прозрачности была поставлена задача экспериментально опре-

\section{SELECTION OF SPECTRAL RANGE FOR SCREENING SYSTEMS}

\section{IN THE TERAHERTZ RANGE}

\author{
V.V.Startsev, V. K. Popov, V.I. Voitov, \\ EDB ASTRON JSC, \\ www.astrohn.ru, www.astrohn.com, \\ Lytkarino, Moscow Region, Russia
}

A complex for detecting prohibited substances when they are hidden in the elements of clothing has been developed. The complex operates in the visible, IR and $\mathrm{THz}$ ranges. Spectral studies of the transmittance of $\mathrm{THz}$ radiation were carried out with samples of packaging materials and fabrics: cotton, denim, wool, pigskin, polyethylene (about $0.2 \mathrm{~mm}$ thick), paper (about $0.2 \mathrm{~mm}$ thick). The frequency range in which all samples of packaging materials and clothing fabrics are most transparent is determined.

Article received for editing 07.05.2019 Article accepted for publication 28.05.2019

1 number of publications on the results of studies of spectral transmittances of terahertz $(\mathrm{THz})$ radiation by tissues and packaging substances are known [1-3]. However, the data obtained in different laboratories are different from each other, so the task of their experimental verification arose. Specialists of EDB Astron JSC carried out such tests at the stage of development of a complex for detecting prohibited substances when they were hidden in clothes. The complex is designed to work in the visible, IR and $\mathrm{THz}$ ranges. These results were presented in a review of the development of $\mathrm{THz}$ detection systems [1]. This article is devoted to the choice of the spectral range that is optimal for the operation of the $\mathrm{THz}$-imaging system.

By the time research began, the unambiguous view of the spectral transmittance of $\mathrm{THz}$ radiation by the atmosphere was not known. Therefore, in order to select the transparency window that is optimal for constructing a THz-imaging system, the task was to experimentally determine the transmittance of $\mathrm{THz}$ radiation by the atmosphere layer.

The choice of the spectral range that is optimal for the operation of the $\mathrm{THz}$ imaging system in the frequency range from 0.02 to $10.00 \mathrm{THz}$ was made on the basis of spectral studies of the transmittance of the $\mathrm{THz}$ radiation from clothing fabric, packaging materials, and an atmosphere layer. 
делить коэффициент пропускания ТГц-излучения слоем атмосферы.

Выбор спектрального диапазона, оптимального для работы ТГц-изображающей системы в области частот от 0,02 до 10,00 ТГц был сделан на основе спектральных исследований коэффициентов пропу скания ТГц-излучения тканью одежды, упаковочными материалами, слоем атмосферы.

При выборе спектрального диапазона был проведен комплекс экспериментально-теоретические исследований:

- проведены спектральные исследования коэффициентов пропускания ТГц-излучения различными упаковочными материалами, тканями одежды с целью определения частотной области, в которой перечисленные среды наиболее прозрачны;

- проведена оценка вклада процесса рассеяния ТГц-излучения в тканях одежды в общий коэффициент пропускания ТГц-излучения средой;

- применен метод [4, 5] математического описания процесса рассеяния ТГц-излучения в тканях одежды; установление связи между спектральным коэффициентом пропускания и структурой материала одежды;

- исследованы спектральные коэффициенты пропускания ТГц-излучения слоем атмосферы с целью выбора оптимального окна прозрачности атмосферы для построения ТГцизображающей системы;

- осуществлен анализ результатов экспериментально-теоретических исследований и сделан выбор оптимального для построения пассивной ТГц-изображающей системы частотного диапазона.

\section{ОБОРУДОВАНИЕ И МЕТОДИКА ИЗМЕРЕНИЙ}

Для достижения перечисленных целей были исследованы спектральные коэффициенты пропускания ТГц-излучения по интенсивности в широком спектральном диапазоне от 0,02 до 10,00 ТГц. В качестве оборудования были использованы ТГцспектрометр во временной области (terahertz timedomain spectrometer) "zOmega" (рис. 1) и иК-Фурье спектрометр «VERTEX 70V» (рис. 2). ТГц-спектрометр "zOmega" позволил регистрировать спектральные характеристики в области частот от 0,02 до 3,00 ТГц, a ИK-Фурье спектрометр "VERTEX 70V" позволил проводить исследования в частотном диапазоне от 1,50 до 10,00 ТГц. Важно отметить, что спектральные диапазоны работы обоих ТГц-спектрометров перекрываются, позволяя охватить всю необходимую область спектра электромагнитных волн.

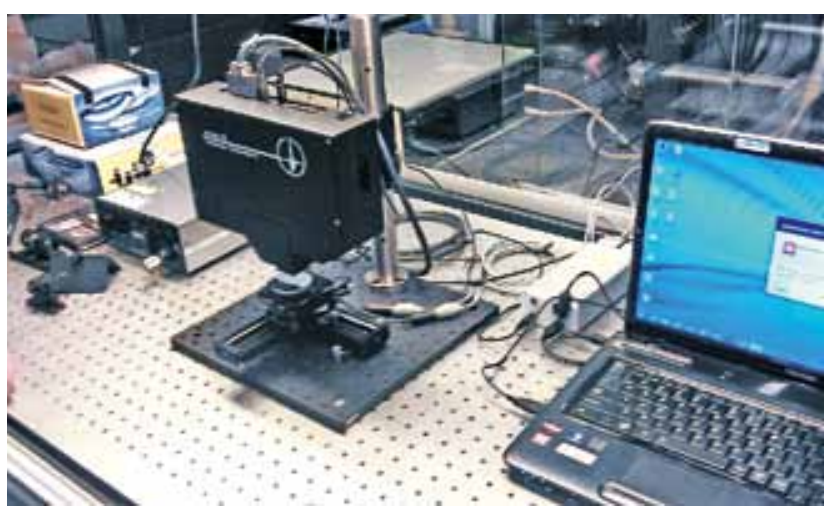

Puc. 1. ТГц-спектрометр во временной области (terahertz time-domain spectrometer) "zOmega"

Fig. 1. THz spectrometer in the time domain (terahertz timedomain spectrometer) "zOmega"

When selecting a spectral range, a set of experimental and theoretical studies was conducted:

- spectral studies of the transmittance of $\mathrm{THz}$ radiation by various packaging materials and clothing fabrics were carried out in order to determine the frequency domain in which the listed media are most transparent;

- the contribution of the THz-radiation scattering process in clothing fabrics to the total transmittance of THz-radiation by the medium was evaluated

- the method [4, 5] of the mathematical description of the process of $\mathrm{THz}$-radiation scattering in clothing fabrics was applied; the establishment of a relationship between the spectral transmittance and the structure of the material of clothing;

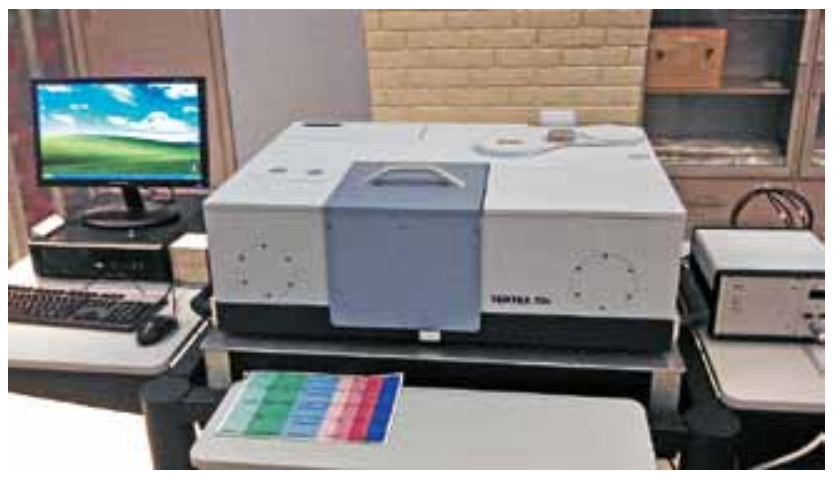

Puc. 2. ИК-Фурье спектрометр "VERTEX 70V»

Fig. 2. FTIR spectrometer "VERTEX 7OV" 
Были проведены спектральные исследования коэффициентов пропускания ТГц-излучения по интенсивности следующими образцами упако вочных материалов и тканей: хлопчатобумажная ткань, джинсовая ткань, шерстяная ткань, шерстя ной свитер, шерстяные брюки, шерстяное пальто, свиная кожа, полиэтилен (толщиной около 0,2 мм), бумага (толщиной около 0,2 мм). На основе резуль татов спектральных исследований была определена область частот, в которой все образцы упаковочных материалов и тканей одежды наиболее прозрачны.

Метод математического описания процесса рассеяния ТГц-излучения в тканях одежды позволил проанализировать влияние процесса рассеяния ТГцизлучения в среде на регистрируемые спектральные характеристики. Проведенные исследования спектрального коэффициента пропускания ТГцизлучения слоем атмосферы позволили опреде лить область частот, в которой атмосфера наиболее прозрачна.

На основе полученных результатов спектральных исследований, результатов изучения процесса рассеяния ТГц-излучения веществом была установлена оптимальная для построения ТГц-изображающей системы область частот.

Терагерцовая спектроскопия во временной области работает за счет зондирования исследуемого объекта коротким импульсом ТГц-излучения длительностью всего в 1,00-2,00 пс [1, 2]. Прошедший через объект или отраженный от объекта сигнал (временная зависимость напряженности электрического поля) регистрируется детектором с высоким времен ным разрешением до 50-100 фс. Короткий импульс ТГц-излучения содержит спектральные составля ющие в диапазоне частот от 0,01 до 3,5 ТГц, что позволяет, используя аппарат фурье-анализа, регистрировать комплексные амплитудные коэффици енты отражения или пропускания ТГц-излучения веществом [6].

Если проводить процедуру регистрации сигналов и обработки зарегистрированных данных в соответ ствии с определенной для этого методикой [7], то с помощью ТГц-спектроскопии можно восстанавливать спектральную зависимость комплексного показателя преломления образца $\tilde{\varepsilon}\left(v_{t}\right)[8]$, а также зависимость оптических характеристик образца от координаты по глубине - профиль оптических характеристик образца $\varepsilon(z)$ [9].

\section{ЭКСПЕРИМЕНТ}

Как генерация, так и детектирование ТГцэлектрического поля с высоким временным раз-
- the spectral transmittances of $\mathrm{THz}$ radiation by the atmosphere layer were investigated in order to select the optimal atmospheric transparency window for constructing a THz imaging system;

- analysis of the results of experimental and theoretical studies was carried out and the choice of the frequency range optimal for the construction of a passive THz-imaging system was made.

\section{EQUIPMENT AND METHODS OF MEASUREMENT}

To achieve the above objectives, spectral transmittances of $\mathrm{THz}$ radiation intensity were investigated in a wide spectral range from 0.02 to 10.00 $\mathrm{THz}$. THz spectrometer in the time domain (terahertz time-domain spectrometer) "zOmega" (Fig. 1) and FT-VIRTEX 70V FT-IR spectrometer (Fig. 2) were used as equipment. The zOmega $\mathrm{THz}$ spectrometer allowed us to record spectral characteristics in the frequency range from 0.02 to $3.00 \mathrm{THz}$, and the VERTEX 70V FTIR spectrometer allowed us to conduct studies in the frequency range from 1.50 to $10.00 \mathrm{THz}$. It is important to note that the spectral ranges of operation of both $\mathrm{THz}$ spectrometers overlap, making it possible to cover the entire necessary region of the spectrum of electromagnetic waves.

Spectral studies of the transmittance of $\mathrm{THz}$ radiation by intensity were carried out with the following samples of packaging materials and fabrics: cotton fabric, denim fabric, wool fabric, wool sweater, wool trousers, wool coat, pigskin, polyethylene (about $0.2 \mathrm{~mm}$ thick), paper (about $0.2 \mathrm{~mm}$ thick). Based on the results of spectral studies, a frequency range was determined in which all samples of packaging materials and clothing fabrics are most transparent.

The method of mathematical description of the $\mathrm{THz}$ radiation scattering process in clothing fabrics made it possible to analyse the influence of the $\mathrm{THz}$ radiation scattering process in the medium on the recorded spectral characteristics. The studies of the spectral transmittance of $\mathrm{THz}$ radiation by the atmosphere layer made it possible to determine the frequency range in which the atmosphere is most transparent.

On the basis of the obtained results of spectral studies, the results of studying the process of $\mathrm{THz}^{-}$ radiation scattering by matter, the optimum frequency range was established for constructing a $\mathrm{THz}$-imaging system.

Terahertz spectroscopy in the time domain is driven by probe study of the object under study with 
решением используют ультракороткие лазерные импульсы оптического диапазона. Генерация и детектирование ТГц-импульсов может осуществляться с помощью эффекта фотопереключения в полупроводнике. Источниками и детекторами ТГц-поля в данном случае являются фотопроводящие антенны. Генерация ТГц-импульсов может производиться с использованием нелинейного эффекта оптического выпрямления в электрооптических кристаллах, а также детектирования за счет исполь зования эффекта Керра в электрооптических кристаллах. Данные эффекты близки друг к другу, так как они определяются одними и теми же коэффициентами тензора нелинейной диэлектрической восприимчивости вещества. Существуют методы генерации и детектирования ТГц-поля в воздушной плазме. Подробно перечисленные методы рассмотрены в работах $[1,2,9]$.

Принципиальная схема терагерцевого спектрометра "zOmega" представлена на рис. 3. В данном спектрометре генерация ТГц-импульсов осуществляется в фотопроводящей антенне, накачиваемой фемтосекундными импульсами волоконного Yb-лазера, а детектирование ТГц-электромагнитного поля осуществляется в электрооптическом детекторе, построенном на основе кристалла ZnTe. Кратко опишем принцип действия ТГц-спектрометра.

Длительность ультракоротких оптических импульсов волоконного лазера составляет 80 фс, а частота их следования 50 МГц.

Пучок фемтосекундного волоконного лазера (ФСВЛ) падает на светоделитель (СД), расщепляется на две части: пучок накачки и пробный пучок, причем пучок накачки имеет большую интенсивность $[4,5]$. a short $\mathrm{THz}$ radiation pulse with a duration of only $1.00-2.00 \mathrm{ps}[1,2]$. A signal passing through an object or reflected from an object (time dependence of the electric field intensity) is recorded by a detector with a high temporal resolution of up to 50-100 fs. A short THz radiation pulse contains spectral components in the frequency range from 0.01 to $3.5 \mathrm{THz}$, which makes it possible, using a Fourier analysis apparatus, to record complex amplitude reflectances or transmittances of $\mathrm{THz}$ radiation by matter [6].

If we carry out the procedure of recording signals and processing the recorded data in accordance with the method defined for this purpose [7], then using $\mathrm{THz}$ spectroscopy it is possible to restore the spectral dependence of the complex sample refractive index $\tilde{\varepsilon}\left(v_{t}\right)$ [8] the depth coordinates are the profile of the optical characteristics of the sample $\varepsilon(z)$ [9].

\section{EXPERIMENT}

Both the generation and detection of the THz-electric field with high temporal resolution use ultrashort laser pulses of the optical range. The generation and detection of $\mathrm{THz}$ pulses can be carried out using the photo-switching effect in a semiconductor. Sources and detectors of $\mathrm{THz}$-fields in this case are photoconductive antennas. The generation of $\mathrm{THz}$ pulses can be carried out using the nonlinear effect of optical rectification in electro-optical crystals, and detection using the Kerr effect in electro-optical crystals. These effects are close to each other, since they are determined by the same coefficients of the nonlinear dielectric susceptibility tensor of a substance. There are methods for generating and detecting a $\mathrm{THz}$ field in an air plasma. These methods are discussed in detail in $[1,2,9]$.

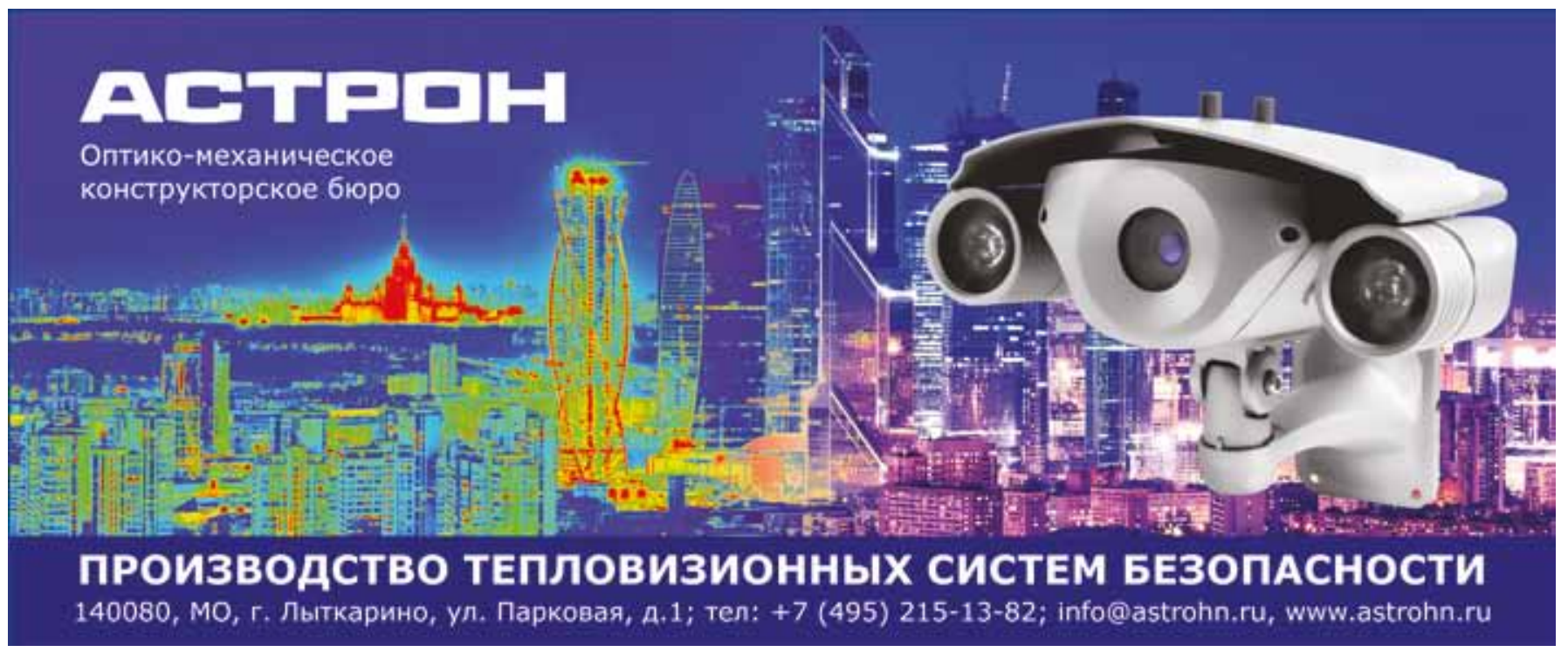

Photonics VOL. 13 № 42019 


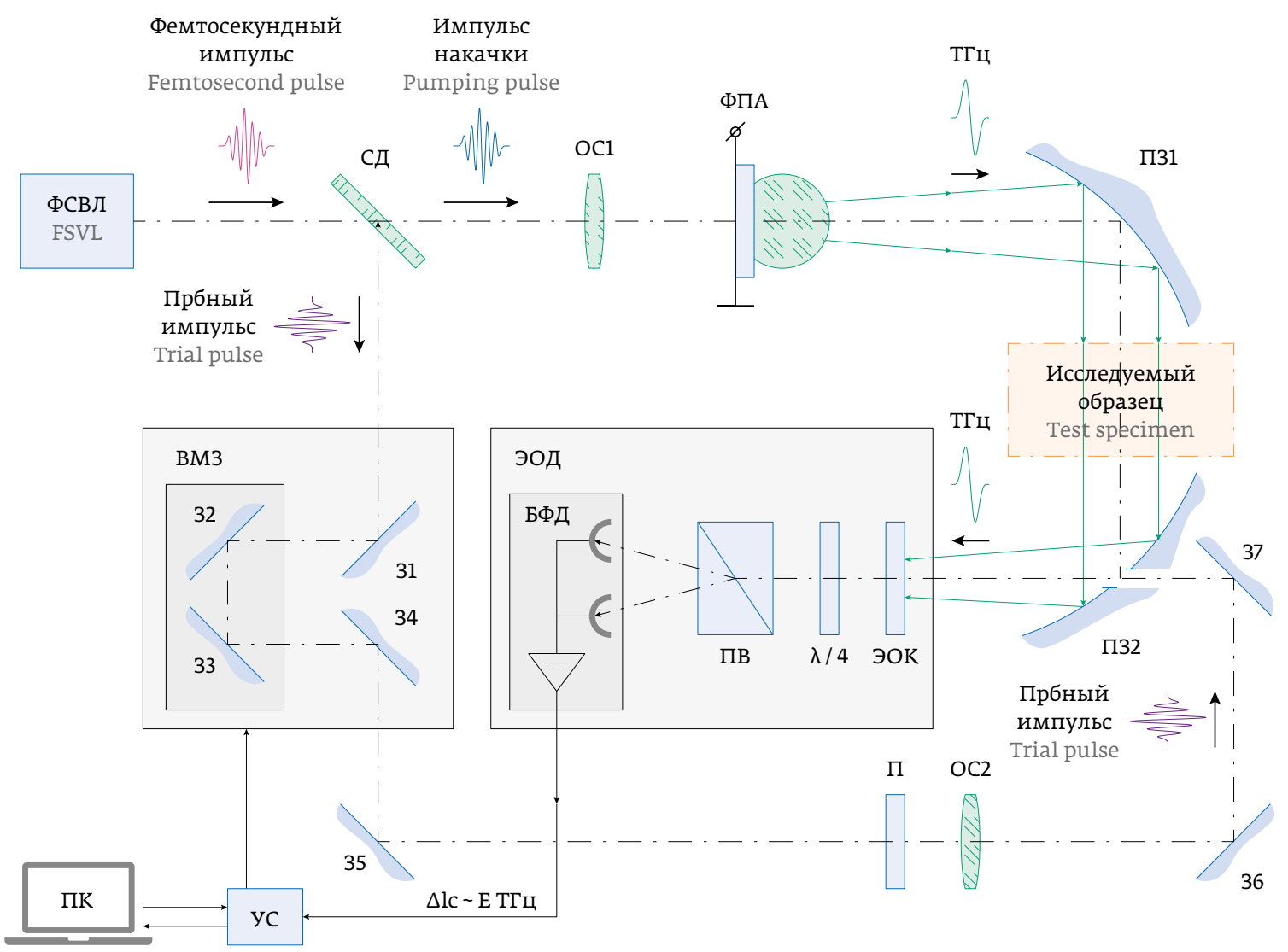

Puс. 3. Принципиальная схема ТГц-спектрометра с временным разрешением с приставкой дяя работы в режиме "на пропускание»: 37-37- плоские зеркала; П37, П32 - параболические зеркала; ОС2, ОС2 - оптические системы; ФСВЛ - фемтосекундный волоконный лазер; СД - светоделитель; ФПА - фотопроводящая антенна; ЭОД - электрооптический детектор ТГи-поля; МВЗ - механическая ветвь задержки; $\Pi$ - поляризатор; $\lambda / 4$ - четвертьволновая пластинка; ПВ призма Волпастона; БФД - балансный фотодетектор оптического сигнала; УС - синхронный усилитель сигнала; ПК портативный компьютер

Fig.3. Schematic diagram of a THz spectrometer with a time resolution with a prefix for operation in the "transmission" mode: Z1-Z7 - flat mirrors; PZ1, PZ2 - parabolic mirrors; OS2, OS2 - optical systems; FSVL - femtosecond fibre laser; BS - beam splitter; PCA - photoconductive antenna; EOD - THz-field electro-optical detector; MDB - mechanical delay branch; P-polarizer; $\lambda / 4$ quarter-wave plate;WP - Wollaston prism; BPD - balanced photodetector of the optical signal; SA - synchronous signal amplifier; $P C$ - portable computer.

Ультракороткие импульсы пучка накачки попадают на диэлектрическую подложку фотопроводящей антенны (ФПА). Каждый оптический импульс накачки участвует в генерации соответствующего ему импульса ТГц-излучения. Типичный вид ТГцимпульса, полученного с помощью фотопроводящей антенны на основе GaAs и зарегистрированного электрооптическим детектором, приведен на рис. 4а, a его амплитудный Фурье-спектр - на рис. 4b.

\section{ОБСУЖДЕНИЕ РЕЗУЛЬТАТОВ}

Рассмотрим результаты спектральных исследований образцов на примере хлопчатобумажной ткани. Для визуализации зарегистрированных графиков
A schematic diagram of the zOmega terahertz spectrometer is shown in Fig. 3. In this spectrometer, the generation of $\mathrm{THz}$ pulses is carried out in a photoconductive antenna pumped by femtosecond pulses of a fibre $\mathrm{Yb}$ laser, and the detection of a $\mathrm{THz}$ electromagnetic field is performed in an electrooptical detector built on the basis of a ZnTe crystal. We briefly describe the principle of operation of the $\mathrm{THz}$ spectrometer.

The duration of ultrashort optical pulses of a fibre laser is $80 \mathrm{fs}$, and their repetition rate is $50 \mathrm{MHz}$.

The beam of a femtosecond fibre laser (FSLV) falls on a beam splitter (BS), splits into two parts: the 

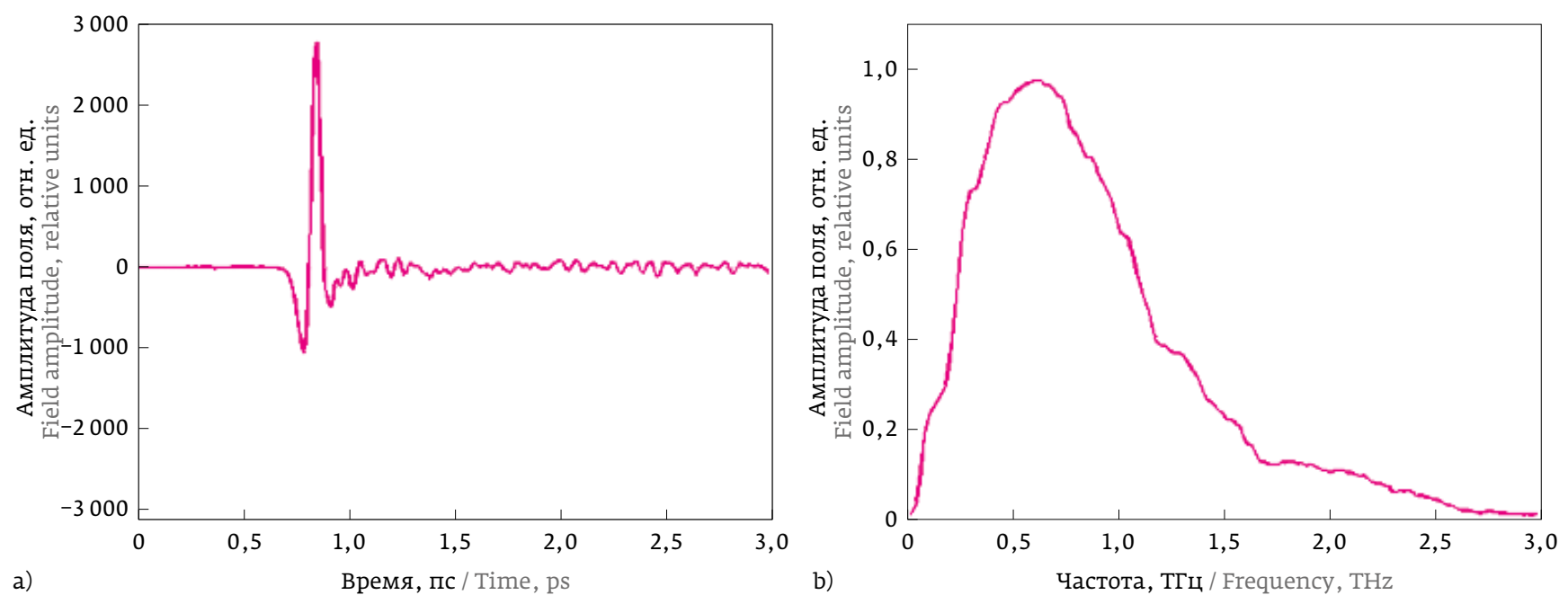

Puc. 4. Характеристики ТГц-излучения, сгенерированного в фотопроводящей антенне на основе GaAs: a) временная зависимость напряженности электрического поля импульса, зарегистрированная с помощью электрооптического детектора, построенного на основе электрооптического кристаляа ZnT; b) амплитудный фурье-спектр Fig. 4. Characteristics of THz radiation generated in a GaAs-based photoconductive antenna: a) time dependence of the electric field strength of a pulse recorded using an electro-optical detector based on an ZnT electro-optical crystal; b) Fourier amplitude spectrum

спектральных коэффициентов пропускания использовался пакет прикладных программ для решения задач технических вычислений MATLAB.

На рис. 5-7 приведены спектральные коэффициенты пропускания по интенсивности ТГц-излучения образцами хлопчатобумажной ткани. Рисунки детализируют графики зависимости спектрального коэффициента пропускания в области от 0,02 ТГц до 0,50 ТГц.

Результаты спектральных исследований образцов хлопчатобумажных тканей показывают, что дан ный вид тканей пропускает более 50\% ТГц-излучения по мощности в частотном диапазоне от 0,02 до 1,00 ТГц. Выше 1,00 ТГц-спектральный коэффициент пропускания сильно спадает, и с 3,00 до 10,00 ТГц его значение близко к нулю.

Аналогичным способом были изучены другие упаковочные материалы. Результаты спектральных исследований и математического моделирования показали, что ТГц-излучение сильно рассеивается в одежде. Для большинства рассмотренных упаковочных материалов, тканей одежды спектральный коэффициент пропускания ТГц-излучения по интенсивности приближается к нулю на частотах выше 1,50-2,50 ТГц. Наиболее сильно ослабление ТГц-излучения происходит при его прохождении через слой свиной кожки, а также через шерстяную одежду . pump beam and the test beam, and the pump beam has a higher intensity $[4,5]$.

Ultrashort pulses of the pump beam fall on the dielectric substrate of the photoconductive antenna (PCA). Each optical pump pulse is involved in the generation of the corresponding $\mathrm{THz}$ radiation pulse. A typical view of a $\mathrm{THz}$ pulse obtained using a $\mathrm{CaAs}^{-}$ based photoconductive antenna and registered with an electro-optical detector is shown in Fig. 4a, and its amplitude Fourier spectrum is shown in Fig. 4b.

\section{DISCUSSION OF THE RESULTS}

Let's consider the results of spectral studies of samples on the example of cotton fabric. To visualize the recorded graphs of spectral transmittances, an application package was used to solve the problems of technical calculations MATLAB.

Fig. 5-7 show the spectral transmittance of $\mathrm{THz}$ radiation intensity by samples of cotton fabric. Fig. 5 details the graph of the spectral transmittance in the region from $0.02 \mathrm{THz}$ to $0.50 \mathrm{THz}$.

The results of spectral studies of samples of cotton fabrics show that this type of fabric transmits more than $50 \%$ of $\mathrm{THz}$ radiation power in the frequency range from 0.02 to $1.00 \mathrm{THz}$. Above $1.00 \mathrm{THz}$-spectral transmittance decreases strongly, and from 3.00 to $10.00 \mathrm{THz}$ its value is close to zero. 


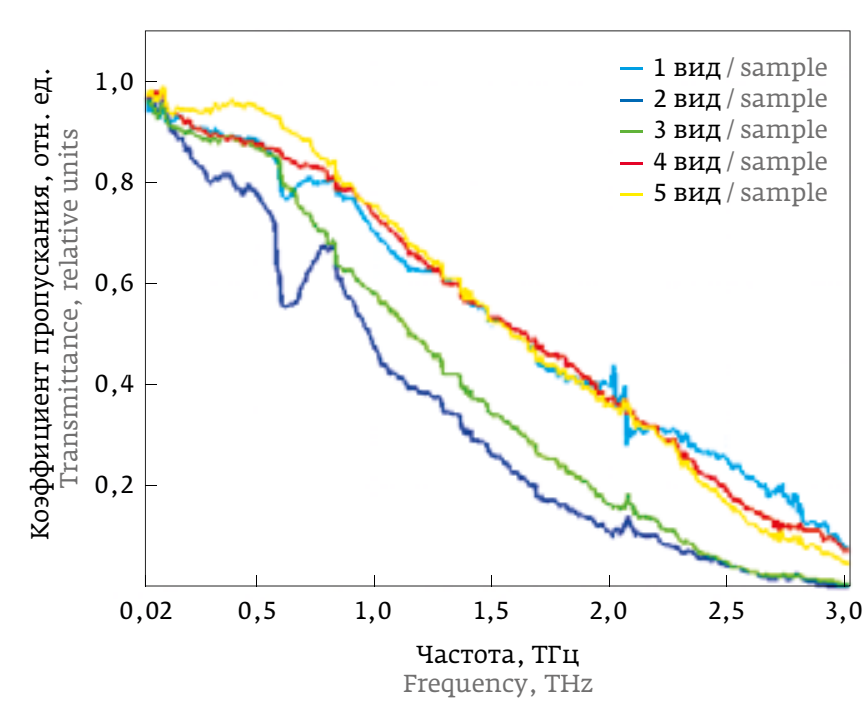

Puс. 5. Спектральные коэффициенты пропускания по интенсивности ТГц-излучения образцами хлопчатобумажной ткани в области частот от 0,02 до 3,00 ТГц

Fig. 5. Spectral transmittance of THz radiation intensity by samples of cotton fabric in the frequency range from 0.02 to $3.00 \mathrm{THz}$

Определено, что шерстяной свитер пропускает более 40\% ТГц-излучения по интенсивности в узкой спектральной области от 0,02 до 0,10 ТГц, а на частотах, меньших 3,5 ТГц, - порядка 5\% ТГц-излучения, являясь наиболее непрозрачной из изученных сред. Выделанная свиная кожа пропускает около 40\% излучения при частоте менее 0,40 ТГц и обладает незначительным пропусканием в спектре до 3,00 ТГц.

На основе проведенных экспериментальнотеоретических исследований мы установили, что ослабление ТГц-излучения в упаковочных материалах и одежде служит препятствием и не позволяет обнаружить скрытый запрещенный предмет на частотах выше 0,35 ТГц.

Было определено, что рабочая частота ТГцизображающей системы должна лежать в диапазоне от 0,02 до 0,35 ТГц.

Существуют и другие факторы, определяющие выбор рабочей частоты ТГц-изображающей системы. Среди них - достижимая разрешающая способность системы, а также ограниченность элементной базы источников и приемников ТГц-излучения.

Очевидно, что предельное разрешение (размер минимально разрешимых деталей объекта) ТГцизображающей системы прямо пропорционально рабочей частоте ТГц-изображающей системы. Для обеспечения возможности обнаружения мелких деталей исследуемого объекта в первую очередь необходимо выбрать максимальную рабочую частоту системы из интервала 0,02-0,35 ТГц.

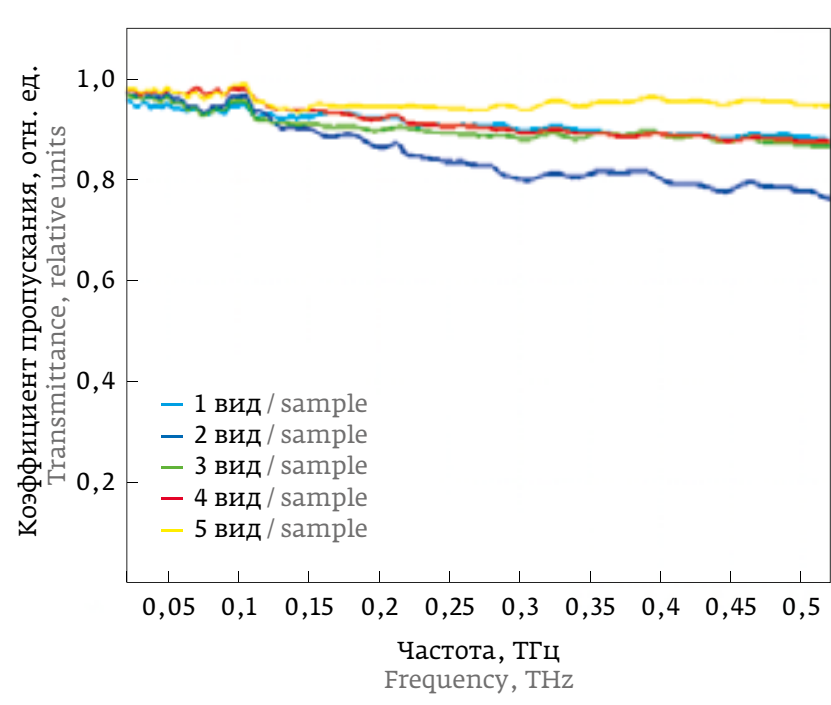

Puc. 6. Спектрапьные коэффициенты пропускания по интенсивности ТГц-излучения образцами хлопчатобумажной ткани в области частот от 0,02 до 0,50 ТГц

Fig. 6. Spectral transmittance of THz radiation intensity by samples of cotton fabric in the frequency range from 0.02 to $0.50 \mathrm{THz}$

In a similar way, other packaging materials were studied. The results of spectral studies and mathematical modelling showed that $\mathrm{THz}$ radiation is strongly scattered in clothing. For most of the considered packaging materials and clothing fabrics, the spectral transmittance of $\mathrm{THz}$ radiation in intensity approaches zero at frequencies above

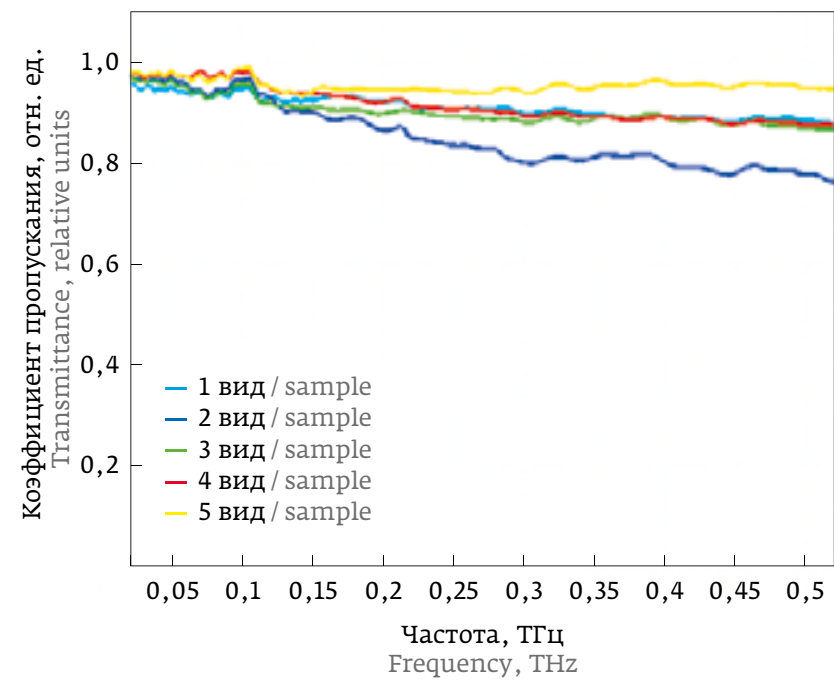

Puc. 7. Спектральные коэффициенты пропускания по интенсивности ТГц-излучения образцами хлопчатобумажной ткани в области частот от 1,50 до 10,00 ТГц

Fig. 7. Spectral transmittance of THz radiation intensity by samples of cotton fabric in the frequency range from 1.50 to 10.00 THz 


\section{ЗАКЛЮЧЕНИЕ}

Для выбора рабочих параметров комплекса ТГцизображающей аппаратуры контроля скрытого проноса в деталях одежды запрещенных веществ установлены связи между спектральным коэффициентом пропускания ТГц-излучения и структурой материала одежды. Обнаружено, что из изученных материалов шерстяной свитер является наиболее непрозрачной средой для ТГц-излучения: он пропускает более $40 \%$ ТГц-излучения по интенсивности в узкой спектральной области от 0,02 до 0,10 ТГц, а на частотах, меньших 3,5 ТГц, - порядка 5\% излучения. Выделанная свиная кожа пропускает около $40 \%$ излучения при частоте менее 0,40 ТГц и обладает незначительным пропускание в спектре до 3,00 ТГц. Определено, что рабочая частота ТГцизображающей системы должна лежать в диапазоне от 0,02 до 0,35 ТГц.

\section{СПИСОК ЛИТЕРАТУРЫ}

1. Старцев В.В., Попов В.К., Наумов А. В. Мультиспектральная система досмотра в ИКи ТГЦ-диапазонах. Фотоника. 2017; 6: 98-112. DOI: 10.22184/1993-7296.2017.66.6.98.112. Starcev V.V., Popov V. K., Naumov A. V. Mul'tispektral'naya sistema dosmotra v IK-iTCC-diapazonah. Fotonika. 2017; 6: 98-112. DOl: 10.22184/1993-7296.2017.66.6.98.112.

2. Lee Y.-S. Principles of Terahertz Science and Technology. Springer. 2009.

3. Gatesman A. J., Danylov A., Goyette T.M. et all. Terahertz Behavior of Optical Components and Common Materials. Proc. of the SPIE. 2006; 6212: 62120E.
1.50-2.50 THz. The $\mathrm{THz}$ radiation is most strongly attenuated when it passes through a layer of pigskin and also through woollen clothes.

It was determined that the wool sweater transmits more than $40 \% \mathrm{THz}$ radiation intensity in a narrow spectral region from 0.02 to $0.10 \mathrm{THz}$, and at frequencies less than $3.5 \mathrm{THz}$, about $5 \% \mathrm{THz}$ radiation, being the most opaque from studied environments Isolated pigskin skin transmits about $40 \%$ of the radiation at a frequency of less than $0.40 \mathrm{THz}$ and has a negligible transmission in the spectrum of up to $3.00 \mathrm{THz}$.

Based on experimental and theoretical studies, we found that attenuation of $\mathrm{THz}$ radiation in packaging materials and clothing is an obstacle and will not allow detecting a hidden prohibited object at frequencies above $0.35 \mathrm{THz}$.

It was determined that the operating frequency of the $\mathrm{THz}$-picture system should be in the range of 0.02 to $0.35 \mathrm{THz}$.

There are other factors that determine the choice of operating frequency THz-imaging system. Among them are the achievable resolution of the system, as well as the limited elemental base of $\mathrm{THz}$ radiation sources and receivers.

\section{ЭССЕНТОПТИКС (|[) ESSENTOPTICS}

\section{PHOTON RT}

\section{Спектрофотометр для Оптиков I Spectrophotometer for Coaters}

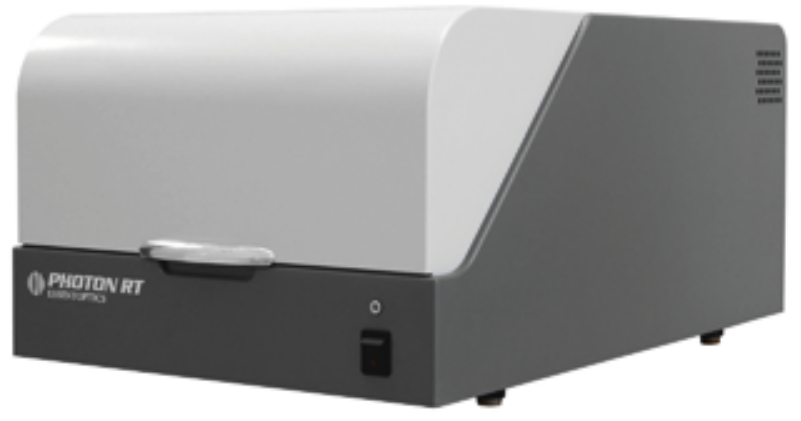

$185-5200 \mathrm{~nm}$ УНИКАЛЬНО ШИРОКИЙ СПЕКТРАЛЬНЫЙ
ДИАПАЗОН В ОДНОМ ПРИБОРЕ

WORLD-RECORD WAVELENGTH RANGE IN ONE INSTRUMENT 
4. Царев М. В. Генерация и регистрация терагерцевого изпучения ультракороткими пазерными импупьсами. Нижний Новгород: Типография ННГУ им. Н. И. Лобачевского. 2010 Carev M.V. Ceneraciya i registraciya teragercevogo izlucheniya ul'trakorotkimi lazernymi impul'sami. Nizhnij Novgorod: Tipografiya NNGU im. N. I. Lobachevskogo. 2010

5. Алехнович В. И., Зайцев К. И., Карасик В. Е., Фокина И. Н. Математическое моделирование процесса рассеяния электромагнитного излучения на проводящих диэлектрических телах сложной формы. Вестник Мгту им. Н. Э. Баумана. Сер. Естественные науки. Спецвыпуск «Прикиадная математика и механика». М.: Изд-во МГТУ им. Н. Э. Баумана. 2012.

Alekhnovich V. I., Zajcev K. I., Karasik V. E., Fokina I. N. Matematicheskoe modelirovanie processa rasseyaniya elektromagnitnogo izlucheniya na provodyashchih dielektricheskih telah slozhnoj formy. Vestnik MGTU im. N. E. Baumana. Ser. Estestvennye nauki. Specvypusk "Prikladnaya matematika i mekhanika". M.: izd-vo MGTU im. N. E. Baumana. 2012.

6. Dickinson J. C., Goyette T. M., Gatesman A. J. Terahertz Imaging of Subjects With Concealed Weapons. Proc. of the SPIE. 2006; 6212: 621200.

7. Reid C. Spectroscopic Methods for Medical Diagnosis at Terahertz Wavelength. A thesis submitted to University College London for the degree of Doctor of Philosophy. 2009.

8. Зайцев К. И., Федоров А. К., Фокина И. Н., Юрченко С. О. Анализ спектральных характеристик воды и льда в ТГц области спектра в процессе фазового перехода. Вестник МГтУ им. Н. Э. Баумана. Серия "Естественные науки". Спецвыпуск "Моделирование физических и технических процессов". М.: Изд-во МГТУ им. Н. Э. Баумана. 2012 Zajcev K. I., Fedorov A. K., Fokina I. N., YUrchenko S. O. Analiz spektral'nyh harakteristik vody i lda v TCc oblasti spektra v processe fazovogo perekhoda. Vestnik MGTU im. N. E. Baumana. Seriya "Estestvennye nauki". Specvypusk "Modelirovanie fizicheskih i tekhnicheskih processov". M.: Izd-vo MGTU im. N. E. Baumana. 2012.

9. Зайцев К. И., Карасик В. Е., Юрченко С. О., Соколова И. В., Рыжий В. И. Диагностика деминерализации эмали зуба с помощью терагерцевой спектроскопии. Вестник МГтУ им. Н.Э. Баумана. Серия «Приборостроение». Спецвыпуск "Современные пробпемы оптотехники. М.: Изд-во МГТУ им. Н. Э. Баумана. 2012.

Zajcev K. I., Karasik V. E., YUrchenko S. O., Sokolova I. V., Ryzhij V. I. Diagnostika demineralizacii emali zuba s pomoshch'yu teragercevoj spektroskopii. Vestnik MGTU im. N. E. Baumana. Seriya "Priborostroenie". Specvypusk "Sovremennye problemy optotekhniki". M.: Izd-vo MGTU im. N. E. Baumana. 2012.
It is obvious that the limiting resolution (the size of the minimum resolvable parts of the object) of the THz-imaging system is directly proportional to the operating frequency of the $\mathrm{THz}$-imaging system. In order to be able to detect small parts of the object under investigation, it is first necessary to select the maximum operating frequency of the system from the interval of $0.02-0.35 \mathrm{THz}$.

\section{CONCLUSION}

In order to select the operating parameters of the $\mathrm{THz}$ imaging complex of the control of hidden transport in the details of the clothes of prohibited substances, links have been established between the spectral transmittance of the THz-radiation and the structure of the material of the clothes. Of the materials studied, a wool sweater was found to be the opaquest medium for $\mathrm{THz}$ radiation: it transmits more than $40 \% \mathrm{THz}$ radiation in intensity in a narrow spectral region from 0.02 to $0.10 \mathrm{THz}$, and at frequencies less than $3.5 \mathrm{THz}$, about $5 \%$ of radiation. Isolated pigskin skin transmits about $40 \%$ of the radiation at a frequency of less than $0.40 \mathrm{THz}$ and has a negligible transmission in the spectrum of up to $3.00 \mathrm{THz}$. It was determined that the operating frequency of the THz-imaging system should be in the range of 0.02 to $0.35 \mathrm{THz}$.

\section{Стандарт частоты рубидиевый ВНИИФТРИ Росстандарта награжден золотой медалью Ha METROEXPO-2019}

\section{Институт Росстандарта ВНИИФТРИ на Между-} народном инновационном форуме и выставке «Точные измерения - основа качества и безопасности» METROEXPO-2019 (15-20 мая 2019) года на площадке ВДНХ в Москве анонсировал свою новую разработку - "сверхминиатюрный стандарт частоты для 5С-сетей и "беспилотников". Разработка стандарта частоты на основе атомов рубидия была отмечена золотой медалью форума. Прибор для генерации высокостабильных сигналов частоты создан на основе инновационных лазерных технологий и технологий квантовой электроники. Он передает единицу времени частоты от эталона средствам измерений. Создание стандартов времени и частоты фонтанного типа на атомах рубидия было вызвано необходимостью массового внедрения отечественных навигационных технологий в инструменты пользователей сетями 5С для синхронизации оборудования и передачи данных в высокоскоростных вычислительных сетях, что особенно важно для проведения финансовых операций в банковской сфере, телекоммуникационных систем, а также инструменты обеспечения безопасного полета беспилотного транспорта. Для этого необходимо было повысить точность передачи единицы времени и частоты.

Цезиевые атомные часы пучкового типа являются эталоном времени. Секунда равна 9192631770 периодам излучения, соответствующего переходу между двумя сверхтонкими уровнями основного состояния атома цезия-133. Если в 2011 году неисключенная систематическая относительная погрешность воспроизведения размера единиц времени и частоты метрологического цезиевого репера частоты типа "Фонтан» (МцР «Фонтан») составляла $\theta_{0} \leq 5 \cdot 10^{-16}$, то у нового стандарта частоты на основе атомов рубидия точность повысилась до $\theta_{0} \leq 5 \cdot 10^{-17}$ за сутки.

Прибор обладает миниатюрными размерами, низким энергопотреблением, высокой стабильностью частоты. Миниатюризация конструкции

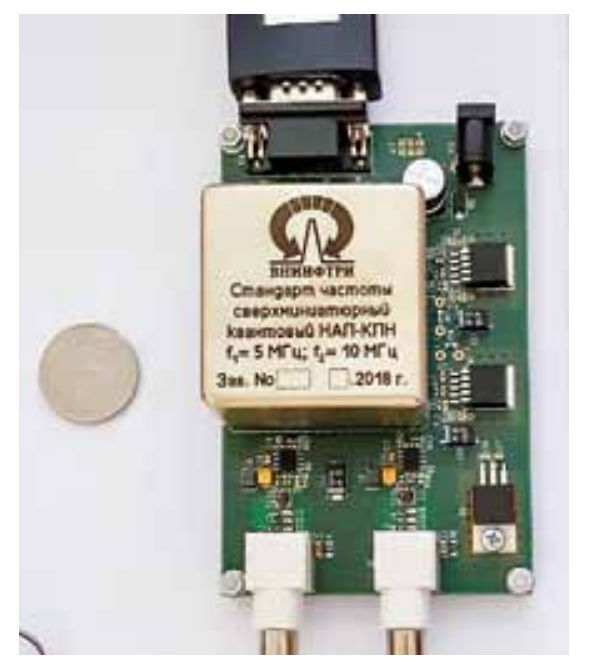

достигнута за счет замены сверхвысокочастотного резонатора миниатюрным лазерным диодом и ячейкой с парами рубидия и буферного газа. Малые размеры прибора позволяют интегрировать их в высокоточные измерительные приборы (анализаторы спектра, анализаторы цепей, осциллографы), что существенно повышает их функциональные характеристики и точность работы.

vniiftri.ru 


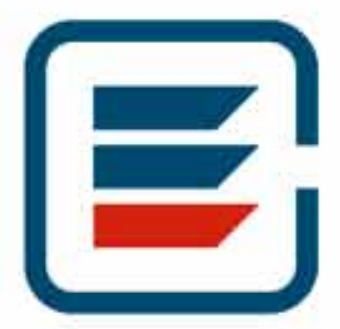

\section{Expo Coating} MOScow

\section{ExpoCoating Moscow}

17-я Международная выставка

материалов и оборудования для обработки поверхности, нанесения покрытий

и гальванических производств

22-24

октября 2019

Москва, Крокус Экспо
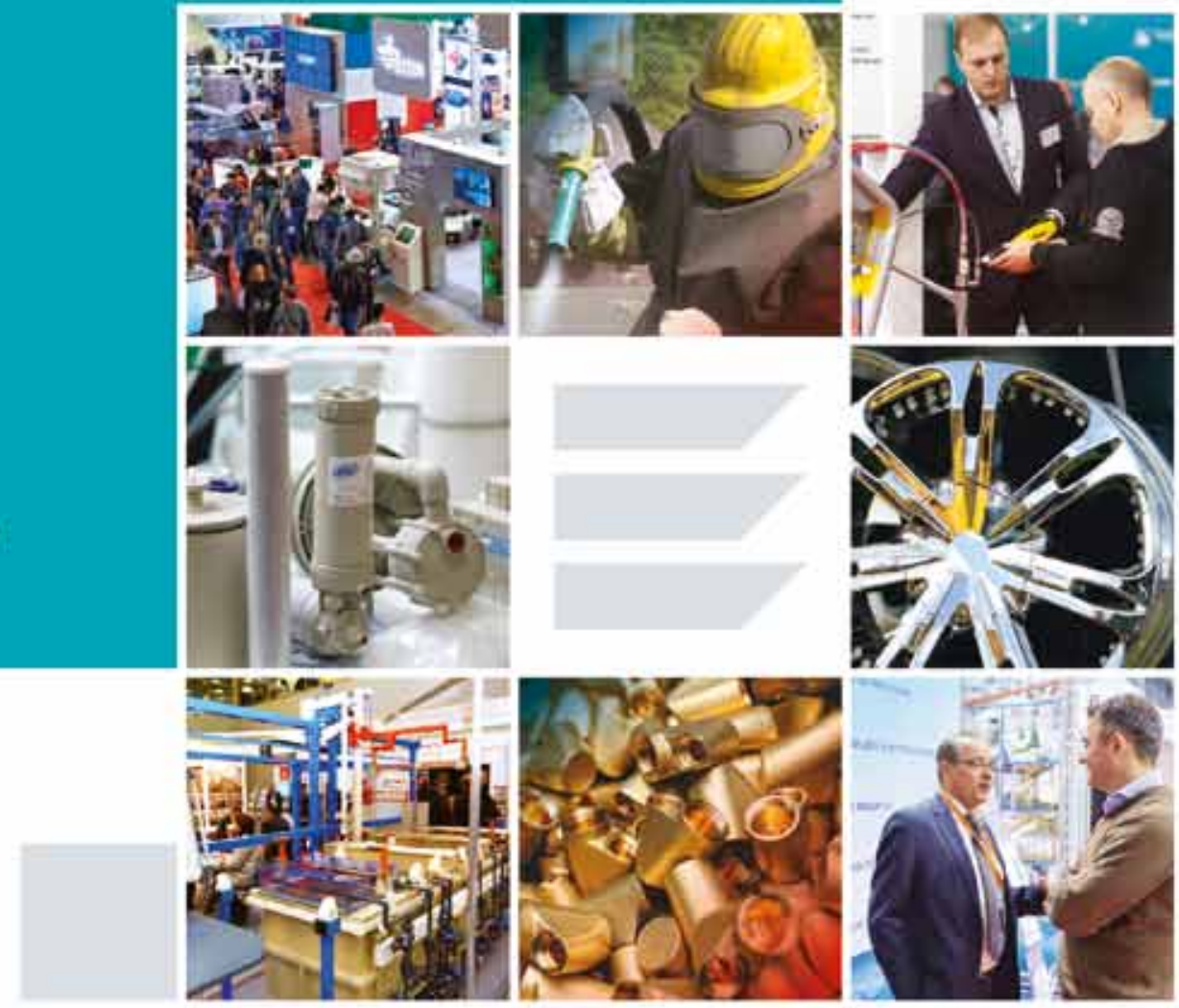

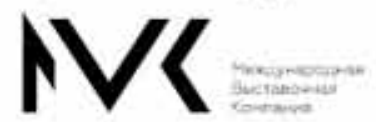

+7 (812) $3806010 / 00$ coating@mvk.ru
Подробнее о выставке:

expocoating-moscow.ru 